\title{
Research on the Construction and Management of Teaching Team in Private Colleges and Universities with Graduate Cultivation
}

\author{
Jingfeng $\mathrm{He}$ and Guangzhen Zhang \\ College of Control Engineering, Xijing University, Xi' an 710123, Shangxi, China \\ 573825625@qq.com,1136481611@qq.com
}

Keywords: Teaching team; Teachers; Private colleges; Team building

\begin{abstract}
This paper explores the value of having graduate training qualifications of private colleges and universities teaching team construction and management, construction content, construction principles, implementation ways, characteristics and the related theoretical issues, that private teaching team in Colleges and universities is a innovation in local colleges and universities teaching organization, is the private colleges and universities lifting level of running a school, the establishment of modern university system.
\end{abstract}

\section{Introduction}

In early 2007, the Ministry of education, the Ministry of Finance jointly launched the "undergraduate teaching quality and teaching reform project", which is an important part of the teaching team and the high level of teaching staff building [1]. Quality is the lifeline of colleges and universities, and improve the quality of teaching, deepening teaching reform, in the final analysis to rely on teachers to improve the professional quality, enhance the teaching quality of [2].

\section{The Characteristics of the Teaching Staff in Private Colleges and Universities}

Xijing University, Beijing City University, Jilin Huaqiao Foreign Languages Institute, Hebei Institute of communications, East University of Heilongjiang, the five private colleges in 2011 to obtain postgraduate training qualifications. This is since the founding of new China, private colleges and universities of our country won the first of postgraduate education qualification, the move marks a private college degree level training to further improve, breaking the past graduate enrollment by public universities, research institutes, and the exclusive monopoly situation.

The five private colleges and universities are in the process of organizing the graduate education. In the training of teachers in the work of the tireless efforts of all aspects of a great improvement. In order to do a good job in the cultivation of graduate students, increase the investment of funds, to strengthen the introduction of the work of teachers. Through in recent years vigorously the introduction, although the overall level of teachers has been greatly improved, but because of the different source of teachers in private colleges, and private colleges and universities hold time is not long, limited accumulation of teachers, there are still some problems: (1) Private college teachers receive less training opportunities. The ratio of students to teachers in the five private colleges and universities relative public colleges and universities teachers is still a shortage of, teacher is still relatively large workload, fewer opportunities for in-service training of teachers, and many private colleges and universities shortage of funds, it is difficult to bear the cost of training. Especially for the part of the need to enhance the level of education teachers, private college teachers cannot be like a public school teacher with pay school to enhance education. In contrast, most of the public colleges and universities to encourage teachers to participate in job training, teachers can not only reimburse some or all of the tuition fees, but also to get promotion opportunities. If the problem is not solved, the gap between private colleges and public colleges and universities in the quality of education is bound to expand, which will eventually harm the interests of private colleges and universities. 
The private university teachers troop mobility is too big. Adopted by the five colleges and universities teachers employment system is the same as the other private schools, teachers do not in people's inherent thinking on behalf of belonging and stable preparation, teachers belonging sense is not strong, School of teacher career development platform lack, teachers cannot see the bright future, can only be directed at the family treatment and, until the wings slightly hard, admitted to the preparation of public colleges and universities, or the civil service exam, or to a higher treatment other private colleges and universities, Faculty mobility, this is bound to improve the young teachers teaching ability and scientific research ability will cause great impact, to raise the seriously affect the quality of teaching.

Private colleges lack in the full vigor of life and have a rich experience in teaching the middle-aged teachers. Cause of this situation: on the one hand is due to the short running time of private universities, source of full-time teachers is mainly fresh masters and doctoral students. On the other hand also because of the private college teachers are not the cause of the preparation, and public universities in salary, welfare and retirement benefits and other aspects have bigger difference, resulting in private colleges and universities it is difficult to recruit the middle-aged backbone teachers and specialized subject leader, cultivate backbone teachers are also vulnerable to the public the benefits and retirement benefits office and other policies to attract and loss rate is higher, resulting in private colleges and universities lack of teacher professional disciplines leaders appear the phenomenon of "fault". Therefore, the "stay" and "flow" of the middle aged backbone teachers is one of the important problems in the human resources department of the private colleges and universities.

Five private colleges and universities teachers, as well as other private colleges teachers, teachers mainly public colleges and universities of the retired teachers and retired from the army colleges and universities teachers, the teachers in the original unit made a lot of achievements, but left the original platform, and left the original team, cannot open display, there is from public colleges and universities over, each teacher's background are not the same, it is difficult to form resultant force, management system and other aspects have undergone great changes. Therefore, it is necessary to a period of time to adjust to the new platform for a new environment.

It is difficult to carry out scientific research in private colleges. Since the graduate education, the quality of teachers in these five private colleges has been greatly improved, to some extent, these five private colleges and universities scientific research activities have been greatly improved. But scientific research has not reached a qualitative leap. This is because the five private colleges and universities with the most private colleges and universities as there is no industry background, there is no industry is bound to affect the development of teaching and scientific research activities and improve the teaching quality of a school, to a great extent, depend on in the teaching and research activities in the University. No industry background is unable to carry out horizontal topic research, even if a teacher to receive a research topic, but very difficult to find a partner, the second is no corresponding experimental platform, and the third is each other of civilian run colleges and universities to receive the degree, the three problems mentioned above has been troubled private colleges and universities in the horizontal scientific research activities. No industry background will affect the development of vertical research topics; it is difficult to find counterparts to bear research topics.

\section{The Necessity of Setting up Teaching Team in Private Colleges and Universities}

With postgraduate education in private colleges and universities in order to comprehensively enhance the school's comprehensive competitiveness and the quality of education and teaching, greatly enhance the teaching and the scientific research ability of teachers must strengthen the building of the contingent of teachers, comprehensively improve the overall quality of teachers, to speed up the development of college education connotation, improve the personnel training quality and level of running a school. Must establish corresponding teaching team, and the construction of teaching team, enhance consciousness of teaching team, establish and team innovation cooperation mechanism, optimizing the overall structure of the teachers, the reform of teaching contents and 
methods development of teaching resources, to promote the exchange of teaching research and teaching experience, promote teaching, help, combining with and the old, middle-aged and young, improve the teachers' teaching and research levels.

The construction of teacher team must to teachers' academic team building and teacher professional growth as the starting point, adhere to the academic autonomy, autonomous teams, academic experts, teaching benefits teachers as well as students of philosophy, to enhance the comprehensive quality of the teachers. In teacher training mechanism, the Institute insists innovative path of internationalization of education, for teachers to create a good professional growth environment, arouse teachers' inner potential, to enhance the school talent cultivation of comprehensive quality and the level of discipline construction, the construction of high level private schools. Through the construction of the team of teachers enhance teachers' team cohesion, research and innovation force, team advantage to promote teachers' comprehensive development and transformation of educational ideas and achieve the improvement of both the team overall level and capacity of individual teachers, which will effectively promote the transformation of school development.

\section{Construction of Teaching Team in Private Colleges and Universities with Graduate Cultivation}

Team building approach should be based on the objectives, content and composition of the team building, and different ways to choose different ways or integrated use of a variety of ways. There are three ways of team building, such as value approach, goal oriented approach and interpersonal relationship approach. Through the values of the way to cultivate a team of teachers on the common values and the rules of the team to reach a consensus, so that the team teachers have a sense of belonging, the formation of team cohesion. In the construction of teaching team in accordance with the goal oriented approach, it can make the members' responsibilities clear and promote the cooperation mechanism within the team [3]. The active teaching and scientific research of the high quality comprehensive teaching team can effectively improve the professional level and comprehensive quality of the team members, so as to promote the teaching and scientific research level of the team members [4].

With clear academic teachers team building direction, can be academic team of course teachers, or scientific research oriented teachers' academic team; the same teacher academic team members in the aspects of teaching content, research direction, contests counseling, laboratory construction, practice base construction must be same or similar.

Teachers' academic team members request belonging to the same department, research team members can take into account inter professional form, establishment principles is conducive to raising teaching quality and scientific research subject, research team can be temporary, after the completion of the project can choose to continue to keep team or in addition to the formation of a team or to return to teaching team.

Configuring team members is the basis for building and cultivating high - level teaching teams. The teaching team usually takes 12 people. But the team members are not just a few people together, to pay attention to the knowledge structure of the team members, professional title structure, age structure, gender structure, personality traits and personal preferences with [5]. In order to promote the development of the teacher's academic team, the formation of complementary advantages of the teacher's academic team structure, the number and structure of the research team can be based on the needs of scientific research topics appropriate flexible configuration.

Improve the system security measures. The teaching team is an important part of the university organization. An efficient and excellent teaching team can only obtain the various human and material resources needed by the effective operation only in the support of the school organization. To create a good system environment, in order to make the teaching team to get a certain system of protection [6-8]. 


\section{The Management of Teaching Team in Private Colleges and Universities}

At the beginning of the term the academic leader of the team of teachers should be organizing its members to study, this semester work plan, and home departments. At the end of the semester by teachers' academic team leader to hospital, debriefing and submit work summary, belongs to the Department issued an audit opinion; audit opinion as teaching assessment basis for division of the academic team.

Teachers' academic team members per person per month at least in a by school organization to observe teaching activities, per person per year speaker a by school organization observe and learn the lesson, participating time and sequence by the teacher's academic team recommended schedule. , the teacher's academic team at least 1 times a week to organize collective lesson preparation activities.

Encourage teachers in all academic team actively cultivate primary grade teachers, especially new teacher and student assistants, teachers' academic team projects or activities participation; reporting topic or project, teachers academic team meeting, held in scientific research activities of teachers' academic team, members should not be less than a junior professional titles of teachers [9].

\section{Examination of Teaching Team in Private Colleges and Universities with Graduate Cultivation}

Assessment cycle teacher academic team every 2 academic year assessment. Teacher assessment is mainly based on teachers in the assessment cycle of teaching and scientific research activities carried out by the assessment of the content of the detailed formulation of the weight coefficient. According to the teacher's completion of the situation and scale factor evaluation. Teachers' academic team assessment score $=$ teachers academic team members of academic team members, the sum of scores and weights of teachers.

Team assessment results are divided into four grades 10]:

Assessment for a teacher academic team, academic team of teachers school based teaching and research funding floating $100 \%$, teachers' academic team members the annual performance appraisal wages and hours of floating $50 \%$, and in the assessment of professional titles recommended;

Assessment of two teachers, academic team, academic team of teachers school based teaching and research funding rising 50\%, teachers' academic team members the annual performance appraisal salary and class fees rising $10 \%$;

Assessment for the three teacher academic team, the academic team of teachers in the next academic year, the basic funding of research and research foundation, the teacher's academic team members of the academic performance of the year's assessment of wages, hours of the same class fee;

Assessment of four grade teacher academic team, academic team of teachers school based teaching and research funding unchanged, teachers' academic team members the annual performance appraisal salary and class fees down 20\%, and delayed a year of job evaluation;

Assessment is below the four level teachers' academic team to be disbanded, the team members to transfer or dismiss the principle.

\section{Summary}

Because of the enormous potential of the teaching team and the pioneering work, the teaching team has become a widely used form of management in Colleges and universities. In the mode of teaching team, the most effective cooperation has been achieved, which forms the interdependence between the individual development and the overall development of the team, and meets the common needs of the teacher growth and the development of the discipline. The wisdom and skill 
of the teaching team, which is a collection of individual teachers, have been promoted to the team's intelligence and skill, which has promoted the course construction, teaching reform and the construction of teaching staff. Management of colleges and universities need to reform and innovation management and evaluation system, to promote the healthy development of teaching team and orderly construction, so that the teaching team this innovative organization can maintain a strong vitality [11].

\section{References}

[1] Li Hongwei, Zhang Liyun. Thinking on the construction of teaching team in Colleges and Universities -- Taking the national teaching team of 2007 and 2008 as an example of [J]. university research and evaluation, 2009 (7/8): 57-61

[2] Yue Huijun, high]. Teacher education and teaching from the perspective of development of teaching team construction in university study [J]. China University teaching, 2010 (5): 13 - 16.

[3] Liu Fengchun, Chen Xiyou et al. Theory and practice of the construction of teaching team in Colleges and universities [J]. Journal of electric and electronic education, 2011 (2): 5-8

[4] Fang Yu, Chen Yashao, et al. Building a high level teaching team to continuously improve the quality of teaching [J]. Chinese university teaching, 2012 (1): 49-52

[5] Diao Shujun. Research on the construction and management of teaching team in Colleges and universities, 2010 (3): 92-93

[6] Li Shufang. Research on the construction of teaching team in Colleges and universities [J]. Heilongjiang higher education research, 2009 (6): 104-106

[7] Chen Xiaolin. Research on the construction mode of teaching team based on the curriculum group [J]. China University of education, 2011 (7): 72-74

[8] Chen Shiping, Peng Yao, Tan Wei. Construction and management of university teaching team [J]. Journal of Chongqing Institute of Technology (SOCIAL SCIENCE), 2008 (6): 152-154

[9] Shuiyan Mei, Li Limin. Construction strategy of university teaching team of [J]. Polytechnic of 2009 higher education (4): 65-67

[10] "Xijing University teacher academic team management approach" are light Jane. To strengthen the construction of teaching team thinking [J]. Journal of the National Institute of education and education, 2009 (1): 27-30 